\title{
Institutions, credibility and crisis: the inconsistencies of Argentine exchange rate policy (1991-2006)
}

NICOLÁS CHERNY*

RESUMO: Este artigo tem dois objetivos. O primeiro é explicar as inconsistências do regime de conversibilidade que levaram à crise de 2001. O argumento sugere que os requisitos de credibilidade para a convertibilidade induziram uma dinâmica de compromissos jurídicos, fiscais, financeiros e externos que aumentaram os custos de saída e inconsistências de tempo. O segundo objetivo é explicar as tensões do regime flutuante que substituiu a conversibilidade em 2002. Nós descrevemos os efeitos de uma taxa de câmbio flutuante em desequilíbrio macroeconômico e a crescente tensão entre a competitividade e a inflação. PALAVRAS-CHAVE: Política econômica; crise da taxa de câmbio; convertibilidade; Argentina.

ABSTRACT: The purpose of this article is twofold. The first is to explain the time inconsistencies of the convertibility regime that led to the 2001 crisis. The argument suggests that the credibility requirements for convertibility induced a dynamic of legal, fiscal, financial and external commitments that increased exit costs and time inconsistencies. The second objective is to explain the tensions of the floating regime that replaced convertibility in 2002. We describe the effects of a floating exchange rate on macroeconomic imbalance and the growing tension between competitiveness and inflation.

KEYWORDS: Economic policy; exchange rate crisis; convertibility; Argentina. JEL Classification: E02; F32; O24.

\section{INTRODUCTION}

This purpose of this article is to explain the inconsistencies that led to the crisis of the Argentine convertibility regime (1991-2001) and the tensions of the managed floating regime that replaced it in 2002. The argument asserts that convertibility management was strongly conditioned by its potential time inconsistencies: the impact of credibility and rigidity interactions on the costs of maintaining

\footnotetext{
* Instituto de Investigaciones de la Facultad de Ciencias Sociales Gino Germani de la Universidad de Buenos Aires. e-mail: nicolas.cherny@gmail.com. Submetido: 1/Novembro/2013; Aprovado: 1/Abril 2014.
} 
or abandoning the regime. Government administration of the floating regime implied a drastic change in the dynamics of the exchange rate. Now officials must address the tension between the search for competitiveness and inflation risks

The article proceeds as follows. In the next section, we explain the sources of imbalance that ended up undermining the sustainability of convertibility over the long term. Here we argue that the time consistency of the currency board crucially depended on the effectiveness of a series of legal, fiscal, external and financial commitments by the government to compensate for the credibility problems of the regime itself. In the third section, we show that the performance of the institutional arrangement for the managed floating system corrected the inconsistencies caused by convertibility, and we show the contrast between the new post-convertibility equilibrium - its rules, incentives, results and risks - and the currency board regime experience. Finally, the last section summarizes the article's findings.

\section{TWO CREDIBILITIES AND THE DYNAMICS OF CONVERTIBILITY}

"Convertibility" was proposed in April 1991 during the first presidency of Carlos Menem (Justicialist Party) after a series of failed stabilization attempts and two hyperinflationary episodes (Palermo and Torre, 1994; Gerchunoff and Torre 1996; Díaz-Bonilla and Schamis, 2001). The government, by Congressional law, fixed the exchange rate to the level of 1 peso $=1$ dollar and prescribed that the Central Bank's international reserves guarantee the circulating money.

Credibility is fundamental for the performance of monetary policy (Kydland and Prescott, 1977; Calvo, 1978) but for convertibility, it was consubstantial (Palermo, 1995). The currency board mechanism is effective because it forces monetary discipline, and thus it returns credibility to the nominal anchor, which, in turn, disciplines prices and wages. However, its time consistency is a problem. As a result, two types of different interacting credibilities can be discerned: an arrangement of structural or long-term credibility to stabilize prices, provided by the currency board mechanism; and a credibility requirement to grant stability to the mechanism aimed at neutralizing the incentives for its abandonment. Consequently, if a government prefers to maintain convertibility, this requirement would submit government to the tireless pursuit of temporary or short-term credibility.

Structural credibility is related to the "monetary rule" of the currency board. The convertibility mechanism induced credibility because the fixed undertaking was based on the fact that the entire monetary base was backed by international reserves, such that the first was attached to the second's level. This, in turn, limited the monetization of fiscal deficits. This mechanism becomes completely credible for the exchange rate anchor because monetary policy holds to the level of international reserves. That is the nature of the currency board. ${ }^{1}$ In this regard, the

\footnotetext{
${ }^{1}$ This structure is more credible than less rigid fixations such as the design of the Brazilian Plan Real in
} 
convertibility set-up provides structural credibility for the nominal anchor, which is very effective for stabilizing persistent inflationary episodes caused by the monetization of the fiscal deficit.

However, no matter how effective the convertibility system was at stabilizing in the short term, its sustainability over the long-term depended on private actors' belief in the currency board mechanism's stability and in the value of their assets implicated in an eventual regime change. ${ }^{2}$ And as the structural mechanism of the currency board rests on the existence of sufficient reserves to sustain the value of the fixed currency, the sustainability of the mechanism depended on capital inflows (or lack of outflows). Such that the monitoring of input and output perspectives of capital flows was a crucial source of credibility that shaped confidence in the sustainability of the mechanism. Since movements in flows of capital are strongly influenced by the international interest rate and the risk rate for emerging markets, an increase to either of these causes a flight of capital. And, as a result, it puts pressure on the international reserves and feeds the currency board's recessive mechanisms: a fall in monetary supply and an increase in interest rate. Flight of capital due to an event external to the domestic economy weakens the foundation of convertibility while also producing negative expectations for future sustainability.

Additionally, there were at least two domestic sources of distrust in the mechanism's sustainability. The first source involves the limitations of counter-cyclical instruments. Since monetary policy was subject to the limits imposed by the quantity of international reserves, the possibility of pursuing real goals rests solely in the fiscal tool, whose margin during convertibility depended on the government's capacity to improve collection and incur debt (pro-cyclical). The government lacked countercyclical tools, such as the exchange rate, and it had a very limited margin for making monetary policy. In addition, the flexibility that the possibility of putting itself in debt granted to it - while voluntary markets were willing to provide it with financingcontrasted with the restrictions that the dynamics of fiscal federalism imposed on it in maintaining convertibility's consistency during the cycle's economic downturns ${ }^{3}$ and that the reform of la Carta Orgánica del Banco Central [The Charter of the Central Bank] (1992) imposed on its capacity to intervene in liquidity and the quality of support for convertibility (Broda and Secco, 1996; Bonvecchi, 2002). ${ }^{4}$

1994 whose fixation left margins and did not completely submit the monetary base to the market (Palermo, 2004).

\footnotetext{
${ }^{2}$ In contrast to the systems that involved monetary substitution - dollarization or a monetary union-, a currency board cannot be completely credible because it can be abandoned.

${ }^{3}$ Lacking institutional capacity to obligate the provincial states to reduce expenses, the government is forced to allow them to incur debt or finance it by increasing partnership transfers (Bonvecchi, 2002).

${ }^{4}$ The reform to the Charter guaranteed the stability and independence of the monetary authority, regulated the extent to which the international reserves that backed the circulating currency could include government bonds issued in foreign currency, granted sources of flexibility, and allowed the BCRA maneuvering room to assist the financial system in the face of an outflow of capital. However, the BCRA's autonomy allowed it to refuse to reduce the quality of the backing - the portion in bonds-
} 
The second source of distrust was the mechanism's potential external fragility and the recessive correction formula for imbalances that unfolded. Convertibility had the potential for inconsistency that tends to make fixations precarious: the inability to correct a misalignment in exchange rate makes it very vulnerable to deficits in the balance of payments. Exchange appreciation in the first years of convertibility - which induced growth with strong purchasing incentives for foreigners - made its consistency dependent on the capacity to generate foreign exchange to finance the current account deficit. The necessary foreign exchange could be acquired by maintaining the inflows of capital or by increasing it through sales abroad. But a sudden retraction of flows (like what happened with the Tequila Effect) or a drop in exports (such as that after Brazil's devaluation in 1999) would cause severe pressure on the reserves and the ability to correct the balance of payments deficits as a result of a downturn in activity (Porta, 1995). Any improvement in competitiveness that the economy experienced under the convertibility regime could be achieved in the short term simply through greater flexibility in lowering the prices of nontradable goods and services and wages and, for the longer term, through a relative increase in productivity. Consequently, the persistence of the balance of payments deficit (which by itself could set off a run against the currency) and the government's difficulty in correcting it without a costly recession (which a government could reasonably wish to avoid) constitute potential incentives for abandoning convertibility. These potential incentives forced the decisionmakers of economic policy to build credibility in capital that would manage to neutralize said incentives for abandonment in order to moderate problems of time inconsistency. ${ }^{5}$ In other words, the effectiveness of the currency board depended on the time consistency that a series of commitments could instill to compensate for the potential incentives for abandonment.

During the ten-year period of convertibility (1991-2001), the credibility capital aimed at ensuring the mechanism's sustainability varied. The Minister of Economy managed to build credibility in several ways: 1 ) sought to restrict the possibilities of changing convertibility by promoting its approval by law; 2) pursued the close of the fiscal gap by maintaining the drive for public service privatization and by adhering to the expense reductions that the bodies providing financing requested in order to release funds; 3 ) provided fiscal benefits to the export sector to minimize the need for foreign exchange; 4) dollarized the public services tariffs and the Central Bank (BCRA, acronym in Spanish) authorized and prompted the nomination of financial

and thereby force the government to reduce its expenses (Bonvecchi, 2002). During the times with pressure on the reserves, the BCRA used said flexibility to confront the deposit withdrawals from the financial system. However, this flexibility was also a source of uncertainty for the agents of the market (Broda and Secco, 1996).

\footnotetext{
${ }^{5}$ Persson and Tabellini (2000), based on the seminal works of Kydland and Prescott (1977) and Calvo (1978), suggest that only the rules that the policymakers do not have incentive to abandon are believable and time consistent. Convertibility was a rule or mechanism whose configuration and dynamics could generate, with the passage of time, incentives for the authorities to prefer abandoning it.
} 
system assets and liabilities in foreign exchange, considerably increasing the costs of a devaluation; and finally, 5) proposed various convertibility exit strategies.

\section{1) Approval by Law}

An exchange rate regime approved by law supposes greater levels of stability and legal effectiveness than a decree and/or exchange rate arrangements made through administrative decisions by the Central Bank. Convertibility's approval by law subjected its abandonment to the government's capacity to construct a parliamentary majority that would approve it, and thus, it increased the requirements for introducing changes to economic policy, decreasing the government's flexibility. However, this did not make it a completely rigid mechanism, given that a government with a majority legislative coalition could change the law. In the case of Menem's government (1989-1999), the PJ [Justicialist Party] held a majority in both chambers of Congress for most part of its two terms such that, if this had been its only obstacle, the government would have been able to change the convertibility law. The resource of law, while making stability dependent on the legislative wishes and capacities of the president, provided legal and practical effectiveness for the consistency and credibility of the commitment. It allowed the government to adapt other legal and administrative decisions to the restrictions imposed by convertibility. If the president did not manage to stabilize the economy under this exchange mechanism and did not have a cohesive legislative majority to change it quickly, he was forced to become an observer of the deterioration and collapse and/ or resign. And, for a president who managed to promote a law to change it, he would have to subject that change - which, as we will see, would imply a general breakdown of contracts - to legal constitutional control of the Corte Suprema de Justicia [Supreme Court of Justice] (CSJ, acronym in Spanish). ${ }^{6}$

Even though the legal nature of the exchange rate regime imposed limits and costs on the president's ability to change it that presented a very powerful reason for a government to avoid making a change, this was not sufficiently convincing in the eyes of the financial operators who, in imbalanced and crisis situations (1992, 1995 and 2001), nevertheless distrusted the willingness of the government to maintain convertibility and/or its capacity to acquire resources and undertake costly decisions aimed at sustaining the fixation regime during times of recession or severe pressure on the international reserves. ${ }^{7}$ As a result, while the resource of law contributed to forming important credibility capital, it was insufficient in the end to neutralize the effects of the potential incentives to abandon convertibility.

\footnotetext{
${ }^{6}$ Díaz Bonilla and Schamis (2001) sustain that the legal nature of convertibility made it nearly impossible for a government to achieve reasonable timing for devaluation.

${ }^{7}$ Due to the constraints of the fixations, the evaluation that the financial operators conduct over the future value of their financial positions decisively influences the sustainability of the exchange rate regime.
} 


\section{2) Reduction of the Fiscal Gap}

The monetary constraint meant that the government could only incur fiscal deficits for which it managed to acquire financing in the voluntary market or through credits from multilateral bodies. The results of the privatizations, the recovery and the Olivera-Tanzi effect during the first few years of convertibility - until 1994 - seemed to indicate that the government could acquire the credibility and resources to moderate the influence of the IMF and finance itself through voluntary markets. However, the structural reduction - over the short and medium term - of fiscal income provoked by the 1994 pension reform, combined with the restrictions of fiscal federalism, placed a strong pressure on government capacity to maintain convertibility's consistency (Llach, 2006 Damill, Frenkel, and Juvenal, 2003).

The circumstances prone to a decrease of fiscal resources - due to increased international interest rate - and an increase of expenses - for example due to electoral cycles - became credibility tests for the stability of the convertibility mechanism. Said situations found the government with limited room for maneuvering in negotiating with the IMF: to sustain international reserves and return credibility to the currency board, the government needed fresh funds, but had to concede cuts in expenses and increases in tax pressure, intensifying the recessive impact of the imbalance. ${ }^{8}$ Nevertheless, by subjecting itself to the recessive mechanisms of the convertibility adjustment and adjusting the fiscal accounts to the IMF's criteria, the government was building a reputation that amplified the credibility of the monetary rule. Additionally, if it could overcome the crisis in the end and manage to again expand production, it would prove that the lack of monetary tools and exchange rate flexibility did not prevent it - with the IMF's guarantee - from confronting shocks, maintaining macroeconomic consistency.

\section{3) Generating Foreign Exchange}

The government's efforts aimed at neutralizing the potential time inconsistency of the balance of payments yielded very partial results. Credibility depended on the capacity to balance the current account deficit trend that exchange rate appreciation causes with foreign exchange from exports and capital inflows.

At the beginning of convertibility, the government eliminated most of the export duties and progressively reduced the import tariffs and eliminated quantitative restrictions (Heymann, 2000). ${ }^{9}$ But two years later the negative impact of the trade

\footnotetext{
${ }^{8}$ In its negotiation with the IMF in March 1995, the government had to increase the VAT from $18 \%$ to $21 \%$ and cut state salaries by $15 \%$ (Llach, 2006). And in order to gain Senate approval for the VAT increase without partnering it with the provinces, it guaranteed the provinces a minimum level of partnering. Said transfer level would be, during the following imbalances, lethal for the national government: it would force it to compensate for the impossibility of sharing the adjustment costs with the provinces with greater reduction of expenses.

${ }^{9}$ The exception was the quotas for the automotive sector.
} 
balance and the demands of internationally exposed sectors over trade policy forced the government -at the end of 1992 - to apply complementary measures aimed at moderating the competition and encouraging exports. Without room to find protection in a currency devaluation, industries competing with imports pushed for antidumping measures, quotas and exemptions (Cherny, 2014).

To moderate dependence on capital inflows, the government planned to increase exports. In this way, it sought to induce favorable behavior in the trade account over the medium and long term, essential for guaranteeing the intertemporal equilibrium of the current account of the balance of payments (Damill, 2000). The launch of MERCOSUR (South American Common Market) combined with the appreciation of the Brazilian currency considerably increased exports - between 1994 and 1998, while the Plan Real was in effect, they doubled — but also increased competition over the local production of tradable goods and imports. ${ }^{10}$ As of 1998, the Brazilian currency devaluation wounded the capacity of the Argentine economy to generate foreign currency, which negatively influenced the propensity of the voluntary markets to continue financing the current account deficit. As a result, the reduction of exports - as of 1999 the recession causes imports to fall as well - and the incapacity to correct the exchange rate misalignment under the convertibility mechanism undermined credibility in the currency board mechanism's sustainability.

\section{4) Dollarization and the Exit Costs}

By increasing the costs of changing the monetary rule for a flexible regime, the nomination in dollars of the public services tariffs and the financial system assets and liabilities worked as decisive reinforcement of the commitment to the currency board's stability. Consequently, local currency devaluation was difficult to reconcile with the rates of public services contracts, and a floating exchange rate was not compatible with the dollarization of the financial system. Leaving convertibility implied measuring the costs of the breakdown of contracts and of "pesification" - converting dollar-denominated accounts and debts to Argentine pesos - versus those of losing the seigniorage and all margin so that the monetary authority could apply the lender of last resort: dollarization.

After the law of convertibility entered into effect, privatizations of public services (telephone, electricity, gas and water) were made under tariff schemes that varied in accordance with the United States inflation index (Gerchunoff, Greco, and Bondorevsky, 2003). The dollarization of tariffs allowed the government to avoid local inertial inflation and to have an exchange insurance to renegotiate down contracts and tariffs with the objective of gaining competitiveness. The exchange

\footnotetext{
${ }^{10}$ There was significant growth in the volume of trade with Brazil and it strongly increased the coefficient of imports in general (in relation to GDP, it went from $6 \%$ at the end of the 1980 s to $20 \%$ in 1997) (Heymann, 2000).
} 
insurance, implicit in the face of an eventual devaluation, widened the exit costs of the fixation and, thus, acted as a neutralizer of the potential incentives for abandoning the monetary rule. However, just as the dollarization of tariffs contributed to the initial consistency of convertibility - inflation in the U.S. was less than the Argentine IPC [Consumer Price Index] - as of 1998 the trend inverted and the tariff framework favored a loss of local competitiveness (Gerchunoff, Greco, and Bondorevsky 2003), which increased the tension between macroeconomic inconsistencies and exit costs.

On the other hand, there are at least two possible interpretations of the causes of the growth in the nomination of the financial system assets and liabilities in dollars. The first suggests that convertibility did nothing more than accentuate a structural tendency present in countries with weak currency. Local currency is accepted as a means of payment but rejected as a store of value by local savers and foreign investors (De la Torre, Yeyati, and Schmukler, 2002). ${ }^{11}$ Under this interpretation we can identify those who occupied the presidency of the Central Bank during convertibility: Roque Fernández (1990-96) - then Minister of Economy (1996-99) - and Pedro Pou, who presided over the BCRA between 1996 and 2001.

From this perspective, the policy options for these countries pose a dilemma. If the government obligates residents to save in local currency, it will cause, in the short term, a flight of capital and maturity mismatch, because savers tend to cut short their investments. By allowing the use of a strong currency within the financial system, the Central Bank moves the foreign exchange risk to credit risk because of uncollectible debts due to a potential mismatch. Thereby it increases the costs of a possible devaluation. However, Levy Yeyati (2002) suggests that the dollarization of the financial system under convertibility does not shut down the risk of noncollectibility, which increases both if there is a devaluation and also if it derives from a contraction triggered by a long deflation of prices.

A slightly different interpretation suggests that, once the economy is stabilized under convertibility, the monetary authority could have created incentives for saving in the local currency and, in this way, progressively generated a larger volume of transactions in pesos and so moderate the preference for the dollar. This position was defended by the Minister of Economy (until 1996) who hoped that stability over the long term together with the backing of the dollar would manage to strengthen the credibility of the local currency. However, facing each uncertainty - the mini run on the peso in 1992 and capital outflows triggered by the Mexican crisis in 1995 - a dynamic that increased the dollarization of the financial system was activated: the Central Bank facilitated coverage in dollars to avoid flight of capital, and savers and financial entities - who pressured for it- opted to hoard in a strong currency. The

\footnotetext{
${ }^{11}$ According to this perspective, the case of Chile shows that the idea of weak currency is distinct from the concept of "original sin." Chile issues external debt in pesos but has managed to establish local currency as a store of value for residents and, in this way, eliminates the maturity mismatch at the domestic level (Levy Yeyati 2002).
} 
BCRA acted in two ways: it facilitated the peso-dollar interchangeability within the financial system, and it covered deposits in pesos with reserves in dollars. The result of this dynamic was, on the one hand, recovery of investors' trust (Ganapolsky and Schmukler, 1998), but on the other, the shaping of a rate differential that discouraged the use of the local currency in the financial system: demand deposits in pesos had the highest reserves in dollars and, at the same time, very low reserves in the term deposits, which were those that people preferred to cover themselves in dollars such that loans in pesos were very expensive and deposits in pesos received lower interest rates (Liendo, 2006). In addition, the need to create credibility about the exchange rate regime mechanism's sustainability left little margin for disagreement about their handling of the economy without the officials converting themselves into sources of uncertainty. Upon the arrival of Roque Fernández as minister, use of deposits in dollars for granting credits was deepened and, with it, the costs of making the regime more flexible. ${ }^{12}$ As observed in Figures 1 and 2, throughout convertibility, hoarding in dollars and indebtedness in foreign currency expanded.

Figure 1: Evolution of Financial System Deposits (1991-2006)

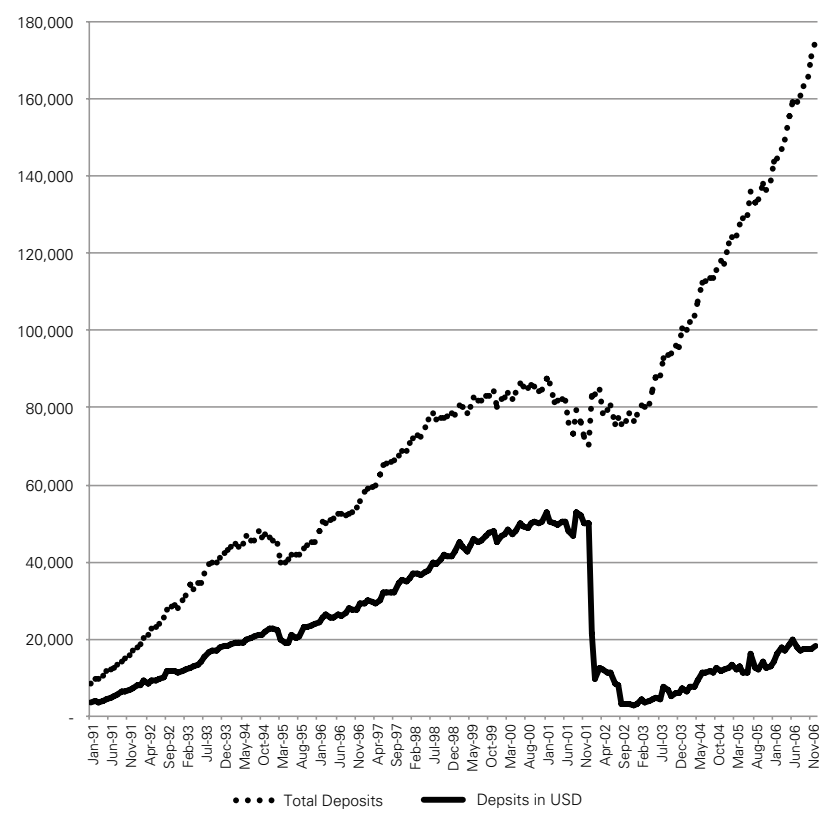

Source: Self-developed using data from the Ministry of Economy of Argentina.

\footnotetext{
${ }^{12}$ Galiani, Tomassi, and Heymann (2003) suggest that the government, upon taking advantage of the opportunity to use the growth of deposits and loans in dollars to mobilize investment, and thereby stimulate growth, underestimated the potential negative of inconsistencies between the magnitude of the commitments and the capacity to repay.
} 


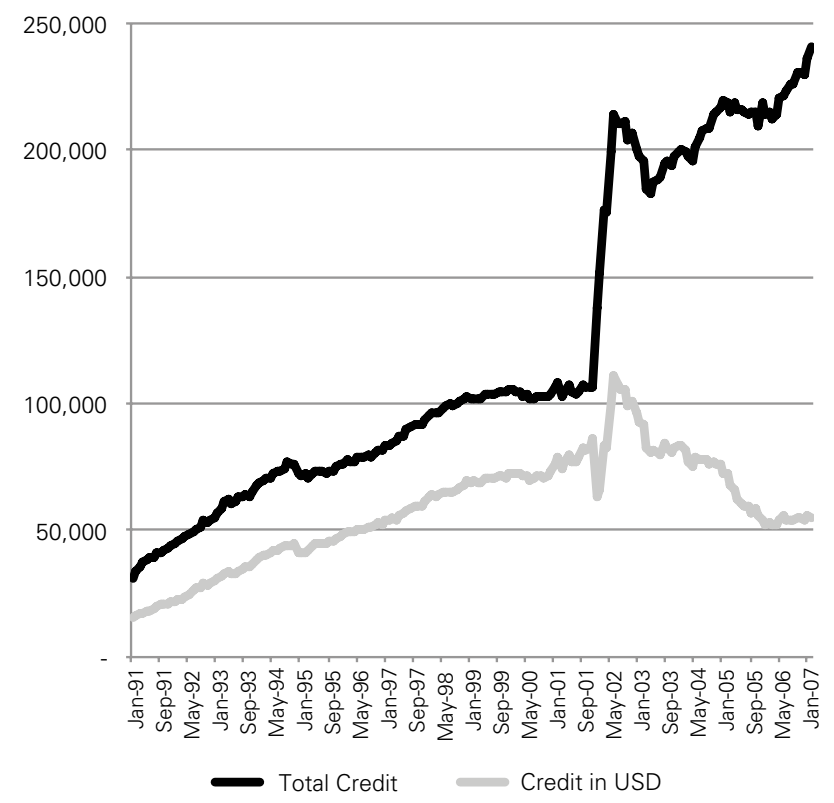

Source: Self-Developed using data from the Ministry of Economy of Argentina.

\section{5) The Escape Valves}

The exit via a nominal devaluation implicated a severe balance sheets adjustment, which worked as a powerful incentive for governments to avoid an exchange rate shift. As a result, the possibility that the government might prefer to leave convertibility by devaluing the currency and, consequently, increasing the risk of breaking down the financial system was low but not zero. As the convertibility mechanism's stability depended on the agents' belief that an eventual abandonment of the monetary rule would not involve a loss of wealth, increasing the regime's sustainability required creating the belief that a possible change in the mechanism of convertibility would guarantee the repayment of debt and the value of deposits. That is to say, the agents' expectation affected the time consistency of the mechanism.

The time consistency of convertibility depended so crucially on the governments' capacity to show that they wanted to and could maintain it that no official was willing to publicly express any doubt about it. However, the economic actors were not indifferent to the means the government was willing to use to resolve the tension between the problems of competitiveness and credibility. By giving priority to the problems of competitiveness - exchange misalignment - the government could be more prone to looking for alternatives to introduce flexibility. Meanwhile, by emphasizing credibility problems - interest rate differential - it would increase 
the willingness to add greater rigidity. Thus, in the flexibility-rigidity spectrum, the government had several possible responses to the question of an eventual change to convertibility: shift to a floating regime, the insertion of flexibility into convertibility, maintaining the status quo, and dollarization.

It can be said that a regime like convertibility was incompatible with a government that publicly expressed its intention to move to flotation in the near future. However, this does not mean that flotation was a less effective regime for resolving some of the problems involved in minimizing loss of wealth: in the face of a contractive period, a devaluation could facilitate economic recovery through exports and generate greater accumulation of foreign exchange and avoid suspending payments (Hausmann and Velasco, 2002). However, it did not resolve the problem of mismatch and, thus, as effective as flotation could have been for certain purposes, by just mentioning this possibility, the government would have very likely set off a self-fulfilling prophecy. There is nevertheless a partial exception to this impossibility. Devaluation is not the only possible result of flotation; in a context of inflows of capital, the local currency should tend to appreciate. ${ }^{13}$ However, the exception is partial because while it is theoretically true, it would be very unlikely to happen in practice. First, because a government lacks incentives to change convertibility at a time of inflows of capital - that is to say, times of economic trust and stimulus-, and second, because experience was showing that a departure from fixed exchange rates - Mexico, Southeast Asia, Russia, Brazil, etc. - caused an overshooting of the currency's price.

The three ministers during convertibility held diverging positions with regards to exit strategy: Domingo Cavallo (1991-96 and 2001) navigated between maintaining the essence of the unaltered status quo and shifting it by introducing some flexibility into the rigidity; Roque Fernández (1996-99) chose strengthening the rigidity through dollarization as an exit strategy; and José Luis Machinea's (19992001) handling sought to show that there was no reason to consider any modification to convertibility.

Cavallo showed, in both handlings - tepidly in the October 1992 episode and decidedly in $2001^{14}$-, that the exit strategy was to maintain the currency board but by modifying the fixation (tying the peso to a basket of currencies), reducing reserves and increasing the percentage of bonds as backing for the monetary base (Mobius, 1999). In this way, he aimed to introduce a dose of flexibility into convertibility that allowed him to reduce the risk of a crisis of balance of payments,

\footnotetext{
${ }^{13}$ Cavallo assumed that convertibility would valorize the peso as much as could have come from a flotation that caused an appreciation of the peso. "Unfortunately, the opportunity of having convertibility without a fixed exchange rate was lost in 1997 and after the Russian and Brazilian crisis, it never arose again" (Cavallo, 2004).

14 "I looked for a middle path, consisting in using all possible non-monetary tools to correct the maladjustment of relative prices, even at the cost of delaying it, but preserving convertibility [...] the idea was to advance toward a more flexible regime, but only after having reinsured the fiscal balance with the reduction of debt interest".(Cavallo, 2002).
} 
obtain some margin for monetary policy-making, and moderate the recessive effects of eventual capital outflows. However, Cavallo's decisions, informed by this propensity to flexibility, produced a loss of credibility for the currency board mechanism both in 1992 and 2001. Said uncertainty was expressed through outflows of capital and runs of different intensities on the currency that compelled the Central Bank to sell international reserves and forced the government to cede to the dollarizing trend of the BCRA's president and/or implement other measures to guarantee debt repayment and the value of deposits.

The change of Minister of Economy in 1996 also triggered a shift in direction on an eventual departure from convertibility. Roque Fernández - Minister - and Pedro Pou - president of the BCRA - held a defined and homogenous position: increase rigidity and credibility of the monetary rule by advancing to dollarization. Despite the fact that the U.S. Federal Reserve's rejection opened discrepancies about its implementation, the idea of dollarization had the approval and promotion of President Menem, who created a Secretary of Strategic Planning attached to the presidency whose priority task was to develop a series of political documents about the benefits of advancing toward dollarization..$^{15}$ The explanation of dollarization, privately before the IMF and much more publicly after the Russian and Brazilian crisis, ${ }^{16}$ acted as an escape valve that reduced the risk of devaluation - identified with the loss of wealth - and, consequently, slowed the outflow of capital and increased the short-term credibility - or moderated the loss - of the currency board.

The arrival of the coalition UCR-FREPASO (Alliance) to government at the end of 1999 and of José Luis Machinea to Minister of Economy implicated a new change in exit strategy. Machinea strategically clung to convertibility: the costs of flotation made it a very risky alternative, adding flexibility to convertibility would have signaled a desire to devalue and, thereby, reduced short-term credibility capital, and dollarization involved "eternalizing" the fixation and, consequently, losing the possibility of restoring monetary policy forever. ${ }^{17} \mathrm{He}$ had three public arguments for rejecting dollarization as an exit and avoiding a loss of credibility: it

\footnotetext{
${ }^{15}$ The rejection on the part of the Federal Reserve of a monetary association with Argentina opened a disagreement about the implementation of dollarization between Minister Fernández and the president of the BCRA, Pedro Pou. While the former considered it essential to conserve at least the returns of the seigniorage and introduce some type of lender of last resort arrangement to the Federal Reserve, the financial uncertainty in 1999 encouraged Pou to promote de facto dollarization to eliminate exchange rate risk (Bonelli, 1999). There was also another source of possible disagreement that came from a diagnostic of the exchange rate misalignment from some of the Minister of Economy's officials: take advantage of dollarization to introduce a devaluation (Kiguel, 2007).

${ }^{16}$ The greatest point of public explanation of the proposal coincides with the presidential proposal of advancing toward paying wages in dollars toward the end of May 1999 (Cavallo, 1999; Rosales, 1999; Rosales and Obarrio 1999; La Nación 1999).

${ }^{17}$ In the words of Machinea: "Convertibility does not need to be touched, it will not be modified for a long time.[...] Dollarization is not an exit from convertibility because dollarization does not leave convertibility, but rather goes beyond it. The problem of convertibility is that it makes the exchange rate permanent, but dollarization eternalizes it" (Machinea, 1999).
} 
reduced room for maneuvering even more, it offered little because the financial system was already dollarized, and it would be much more effective to carry out a monetary union within the framework of Mercosur. ${ }^{18}$ Nevertheless, without the dollarization escape valve, he lost a source of extra credibility for confronting times of temporary imbalance.

In sum, maintaining the convertibility mechanism forced decision-makers to pursue the mechanism's sustainability. But at the same time, said pursuit caused the authorities to magnify the costs of a change. Convertibility had two phases of growth: 7.6\% per year between 1990 and 1994, a fall following the Mexican crisis, then recovery starting in 1996, and finally, from the second quarter of 1998 through the last quarter of 2001 , production fell by $15.6 \%$. The accumulation of distortions intensified after the Brazilian devaluation (1999) and created, starting in 2000, a crisis dynamic: the downturn in activity impacted the fiscal accounts, and investors' trust in capacity to repay public debt fell.

\section{THE EVOLUTION AND TENSIONS OF MANAGED FLOTATION (2002-2006)}

The literature suggests that there are two ways to manage flotation: the fear of inflation activates an intervention directed at avoiding devaluation, and fear of losing competitiveness causes behaviors aimed at avoiding appreciation and the so-called "Dutch disease"19 (Levy Yeyati and Sturzenegger, 2007; Bresser-Pereira, 2008). The decision-makers adopt arrangements that allow currency floating because they provide greater flexibility for monetary and exchange rate policy, and it grants them room to use them with the objective of affecting real goals, such as stimulation of economic activity and competitiveness (Broz and Frieden, 2006; Corden, 2000).

Post-convertibility economic evolution was marked by the dynamic of crisis and the costs of changing the exchange rate regime from a currency board to flotation. The improvement in competitiveness granted by the devaluation and the recovery of the monetary tool allowed for rearranging the macroeconomy, but the difficulties in stabilizing the currency in a context of very reduced monetary and

\footnotetext{
18 "The idea is that in the future, confidence can be reestablished in the currency to recover a monetary policy of our own. With 'our own' I am also referring to Mercosur. [...] We have to discuss today whether we have a unique currency, and whether it suits us to create one for Mercosur, or adopt an existing one, such as the dollar. [...] Mercosur policy needs discussing before proposing such an idea," asserted Machinea during the Alliance's electoral campaign (Machinea, 1999).

${ }^{19}$ Intervention aimed at avoiding depreciation - "fear of floating"- tends to be related to defense of the currency in the face of a financial crisis. Meanwhile, to slow currency appreciation, the intervention is associated with contexts of high export prices (Dutch disease) and entry of foreign exchange, and manages to preserve competitiveness and, with it, economic growth.
} 
fiscal resources, ${ }^{20}$ the throes of the private and public financial collapse and the loss of wealth and consumption capacity obstructed the potential for recovery for long months. ${ }^{21}$

Figure 3: GDP vs. Inflation (1997-2005)

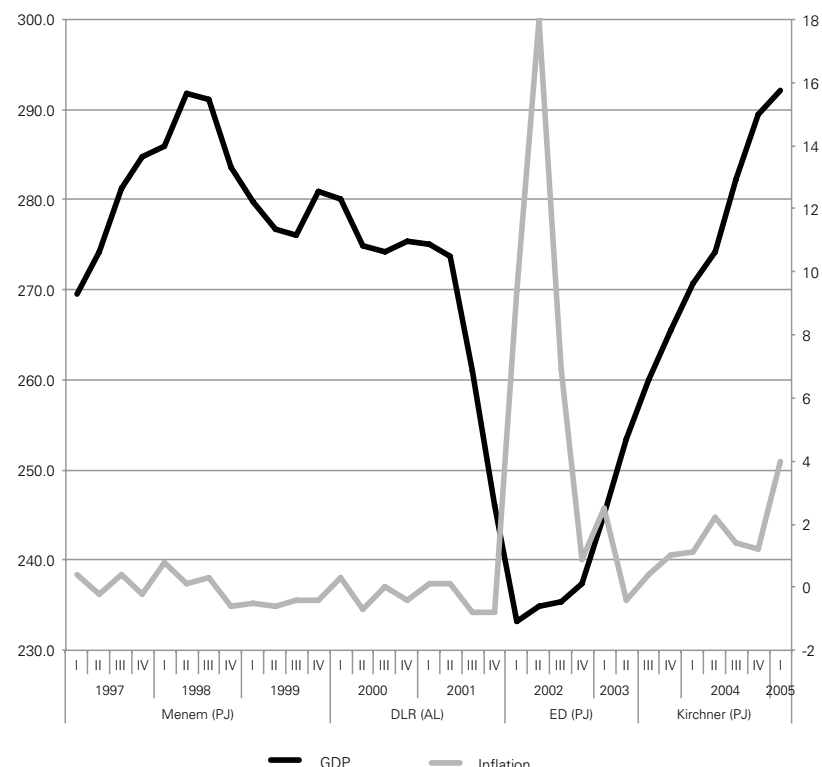

Source: Self-developed using data from the Ministry of Economy of Argentina.

The pesification of the financial system's deposits and credits moderated the effects of the mismatch and with it, the contractive impact of the devaluation derived from the alteration in the economic agents' balance sheet (Hausmann and Velasc, 2002; Remes Lenicov, Todesca, and Ratti, 2003). ${ }^{22}$ After the devaluation,

${ }^{20}$ To contain the initial overreaction, the government split the exchange market: one official exchange rate at 1.40 pesos per dollar - which meant an initial devaluation of $28.6 \%$ of the local currency - and another free. But in just a few weeks, the government prescribed its unification in one free-floating market exchange.

${ }^{21}$ The devaluation produced during the first quarter of 2002 provoked a pronounced rise in internal prices - in April, an increase of $21 \%$ had already been accumulated - and, therefore, a fall in average real salaries of almost $18 \%$, whose impact on consumption accentuated the decline of aggregate demand which quickly fell as of midway through 2001. However the pass-through ended up low compared with other devaluation experiences: the nominal exchange rate during the first half of 2002 increased by $260 \%$ and, despite the rise of internal prices, the real exchange rate (RER) increased close to $180 \%$ (Rapetti, 2005).

${ }^{22}$ According to the literature, the level of financial dollarization determines if the exchange rate is a counter-cyclical tool capable of absorbing shocks or if it is a pro-cyclical source of economic contraction (Frankel, 2005). However, there were disagreements about the effects that it would produce in this 
Figure 4: Real Exchange Rate - Argentina 1991-2008

Multilateral RER, \$Arg vs. Real, \$Arg vs. Dollar

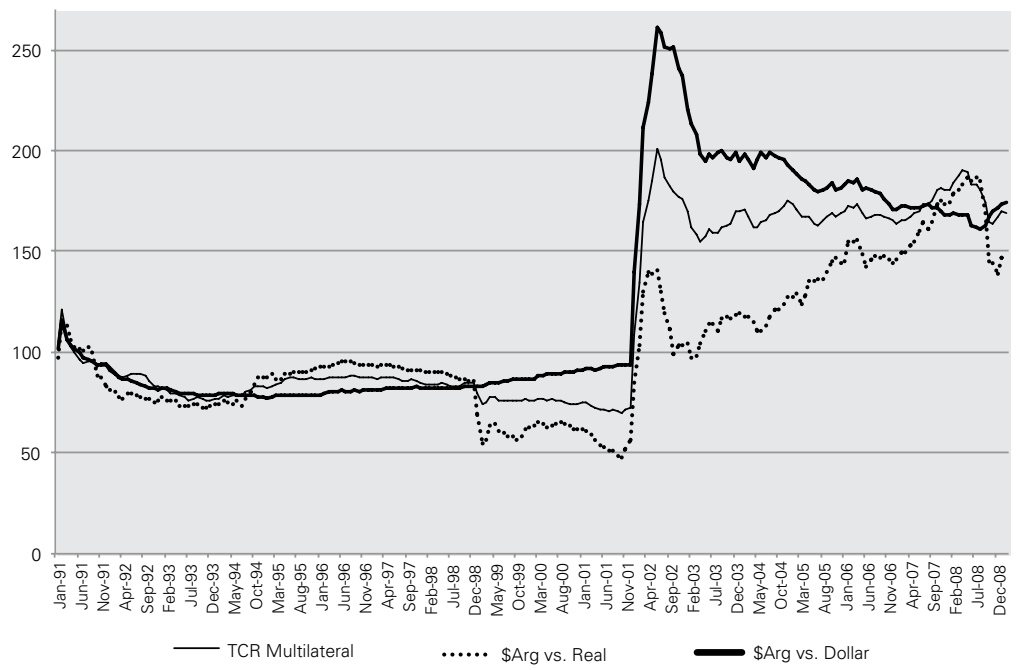

Source: Self-developed using data from the Ministry of Economy of Argentina.

the real exchange rate was kept at historically high values that improved the terms of trade and changed the growth pattern. ${ }^{23}$

The extraordinary rise of commodities allowed the government to maintain export withholding taxes that promoted collection, and the restructuring of the debt contributed to reducing the flow of future payments (Gerchunoff and Aguirre, 2004; Cetrángolo, Heymann, and Ramos, 2007; Gerchunoff, 2005; Damill, Frenkel, and Rapetti, 2005). ${ }^{24}$ Under this scheme, accelerated economic recovery produced rapid growth in fiscal income in relation to expenses: the primary and financial output surplus was a salient feature of the post-convertibility period. ${ }^{25}$

The managed flotation allowed for, in the first place, transcending the traditional external restriction -that tended to halt expansions of activity- and gain trade surpluses. In this way, dependence on external savings to finance sustained growth was moderated. Secondly, it prompted improved fiscal performance and created a

context. There were those who considered the maladjustment between assets and liabilities an unavoidable contractive effect (Calvo, Izquierdo, and Loo-Kung, 2005) and there were those who proposed pesification as an exit.

${ }^{23}$ The relationship between exports and private consumption grew from $15 \%$ in 1998 to $40 \%$ in 2006 (Cetrángolo, Heymann, and Ramos, 2007).

${ }^{24}$ The combination of high export prices and undervalued exchange rate had created an extraordinary margin of profitability in the exportation of commodities susceptible to tax payments.

${ }^{25}$ The relative value of payments to personnel and of welfare transfers in contrast to a very significant increase of GDP in current pesos (Cetrángolo, Heymann, and Ramos, 2007). 
greater margin for maneuvering the management of fiscal accounts. Finally, maintaining a devalued exchange rate stimulated local production of goods strongly linked to employment - tradable ones - above all exportable, but also those intended to substitute imports in the internal market (Frenkel and Rapetti, 2005, 2012).

However, the maintenance of competitiveness that nominal devaluation had granted to the tradable sector was not exempt from tensions in its management and time inconsistencies. On one side, economic stabilization and reversion of the economic cycle reversed the outflow of capital and increased the foreign currency supply by pushing a revaluation of the local currency. ${ }^{26}$ On the other, there are two elements that exerted pressure on domestic prices and whose persistence along time mined the competitiveness gained by the intervention over the currency price. First, the trend toward increasing the reserves that back the monetary aggregates, which is associated with an accumulated increase in the real exchange rate, exerted pressure on domestic prices (Levy Yeyati and Sturzenegger, 2007). Thus, the sustainability of an undervalued exchange level depended on the way that the Central Bank resolved the tension between the progressive increase in the need to issue local currency to intervene in the exchange market - and avoid a nominal appreciation of the peso - and the inflationary impact of that issuing, which would cause real appreciation (Frenkel, 2006). Secondly, the effects of that issuing on balance cause salary demands that, in the Argentine case, took on their own dynamic and, therefore, fed the classic competition between inflation and salaries.

In this context, two elements allowed the government to maintain a managed flotation oriented towards competitiveness (MFC) with relative effectiveness: a strong capacity of influence over the Central Bank and the launch of a mechanism to absorb the portion of monetary issue susceptible of putting the annual inflation goals at risk. In the first case, the influence is crucial: while the Central Bank is formally autonomous, its president and directorate are appointed by the Executive Power with the Senate's approval. In the second, the results are more controversial. The monetary issue needed to "fictitiously" maintain the peso sufficiently depreciated to guarantee a wide competitive margin for local production was relatively well absorbed in a satisfactory way until the end of 2005 by the Central Bank issuing bills. However, the persistence of the monetary issue combined with high economic growth (at an average of $8 \%$ between 2003 and 2007), the dynamic of concessions and salary demands and the reduction of the fiscal surplus began to impact the price index and awaken inflationary expectations. Accordingly, as of 2006 , inflation progressively escalated, and the government was able to only partially moderate its increase by expanding the intensity and scope of its intervention in pricing (through subsidies and controls).

\footnotetext{
${ }^{26}$ Among the factors that push for a revaluation of the peso, one that stands out is the growing trade surplus that the country began to show in part because of the fall in imports and in good part due to the exponential increase of exports.
} 


\section{CONCLUSIONS}

Convertibility was a very effective mechanism for stabilizing prices but it had high demands on short-term credibility that caused an increase in exit costs. By not completely eliminating the risks of devaluation, a good part of the decisions aimed at returning or strengthening the convertibility mechanism's time consistency were oriented with growing intensity toward a considerable increase in the inconsistencies of an eventual change in exchange rate regime. And, as a consequence, the decisions moved progressively toward reducing the range of options for the decision-makers of economic policy.

Convertibility could be confronted with two types of imbalance of distinct intensity: a run on the reserves and the currency whose origin is exogenous to the foundations of the domestic economy - caused by the contagion of other emerging economies or increases in the international interest rate - or, a severe exogenous or endogenous pressure on the international reserves or the currency that operates on the already weakened economic foundations. Said imbalances placed the governments in dilemmas that grew in intensity over time. A first option was to stabilize the economy by raising the stakes of credibility with more dollarization and rigidity and deferring costs for the future. The other option was stabilization based on making the exchange rate regime more flexible: produce a devaluation and adhere to the costs of the collapse of the private sector's balance sheets and the suspension of debt payments. Consequently, maintaining convertibility depended in large measure on the government's economic resources - access to voluntary credit or credit from international bodies - to refinance debt maturities and back convertibility with international reserves, and on the relative weight of preferences it held in the trade-off between implementing the recessive adjustment caused by the currency board -or an eventual complete dollarization - and confronting the costs of the financial collapse involved in the change.

While the transaction costs of the change to flotation were enormous, the managed flotation resolved a good part of convertibility's rigidities: the exchange rate misalignment, the external vulnerability, and the lack of counter-cyclical tools. After stabilization, between 2002 and 2005 the authorities were able to manage the potential inconsistency that arose from the tension between the objectives of competitiveness and inflation. For this, they signaled their preference for competitiveness with interventions in the exchange market that deterred expectations of a revaluation of the local currency and managed to control the monetary expansion by surplus sterilization. With this the government managed to accumulate international reserves that allowed it to manage flotation, maintain a solid fiscal surplus based on tax revenues collected from exports and the resurgence of consumer spending, stimulate a high rhythm of growth and strongly decrease unemployment, at the same time that it avoided the classic bottlenecks of the balance of payments - maintaining the trade surplus and minimizing dependence on external saving. However, as of 2006, the economic reheating and expansion of fiscal spending caused a persistent rise in inflation, restricting the possibilities of using exchange rate flexibility to maintain competitiveness and, therefore, limiting the MFC's effectiveness. 


\section{REFERENCES}

BONELLI, M. (1999) “La Dolarización Divide Opiniones En El Gobierno.” Diario Clarín, May 27. Http://Www.Clarin.Com/Diario/1999/05/27/O-00301d.Htm.

BONVECCHI, A. (2002) "Estrategia de supervivencia y disuasión. Los procesos políticos de la política económica después de las reformas estructurales.” In El Derrumbe Político En El Ocaso De La Convertibilidad, Edited By M. Novaro, 107-94. Buenos Aires: Norma.

BRESSER-PEREIRA, L. C. (2008) "The Dutch disease and its neutralization: a ricardian approach" Revista de Economia Política 28 (1): 47-71.

BRODA, M. A., and L. SECCO. (1996) "Caja de conversión pura o un banco central con límites estrictos? Las Ventajas de la flexibilidad durante la crisis del primer trimestre de 1995." Anales De La 31a. Reunión Anual De La Asociación Argentina De Economía Política 2.

BROZ, J., and J. FRIEDEN (2006) "The political economy of exchange rates." In The Oxford Handbook Of Political Economy, Edited By Barry R. Weingast And Donald A. Wittman. Oxford University Press.

CALVO, G. (1978) "On the time consistency of optimal policy in a monetary economy." Econometrica 46 (6): 1411-28.

CALVO, G., Alejandro IZQUIERDO, and Rudy LOO-KUNG. (2005) Relative Price Volatility Under Sudden Stops: The Relevance Of Balance Sheet Effects. National Bureau Of Economic Research. Http://Www.Nber.Org/Papers/W11492.

CAVALLO, D. (1999) La dolarización es un error garrafal. Http://Www.Clarin.Com/Suplementos/ Economico/1999/01/24/O-00401e.Htm.

. (2002) "El aumento de la desocupación y la pobreza." Http://Www.Cavallo.Com.Ar/?P=95.

. (2004) "Lectures delivered at the department of economics, Harvard University." Http://Www. Cavallo.Com.Ar/?Page_Id $=80$.

CETRÁNGOLO, O., D. HEYMANN, and A. RAMOS. (2007) “II. Macroeconomía en recuperación: La Argentina post-crisis." Crisis, Recuperación Y Nuevos Dilemas. La Economía Argentina 2002$2007,27$.

CHERNY, N. (2014) "The Influence of interest groups on government the case of the 2001 Argentine crisis.” Latin American Perspectives, May, 0094582X14535718.

CORDEN, W. M. (2000) “Exchange Rate regimes and policies: an overview.” In Exchange Rate Politics In Latin America, edited By C. Wise And R. Roett. Washington, DC: Brookings Institution Press.

DAMILL, M. (2000) "El balance de pagos y la deuda externa pública bajo la convertibilidad." Boletín Informativo Techint 303. Http://Cdi.Mecon.Gov.Ar/Biblio/Docelec/MU2457.Pdf.

DAMILL, M., R. FRENKEL, and L. JUVENAL. (2003) "Las cuentas publicas y la crisis de la convertibilidad en la Argentina." Desarrollo Económico, 203-30.

DAMILL, M., R. FRENKEL, and M. RAPETTI. (2005) "La deuda Argentina: Historia, default y reestructuracion." CEDES Nuevos Documentos 16.

DE LA TORRE, Augusto, Eduardo Levy YEYATI, and Sergio L. SCHMUKLER. (2002) "Argentina's financial crisis: Floating money, sinking banking." The World Bank, Mimeo, April. Http://Www. Econ.Umn.Edu/ Tkehoe/Classes/Schmukler.Pdf.

DÍAZ-BONILLA, E., and H. E. SCHAMIS. (2001) "From redistribution to stability: the evolution of exchange rate policies in Argentina, 1950-98.” In The Currency Game Exchange Rate Politics In Latin America, edited by J. Frieden And E. Stein: 63-118.

FRANKEL, J. (2005) Contractionary Currency Crashes In Developing Countries. National Bureau Of Economic Research Cambridge, Mass., USA. Http://Www.Nber.Org/Papers/W11508.

FRENKEL, R. (2006) "An alternative to inflation targeting in Latin America: Macroeconomic policies focused on employment." Journal of Post Keynesian Economics 28 (4): 573-91.

FRENKEL, R., and M. RAPETTI. (2005) "Monetary and exchange rate policies in Argentina after the convertibility regime collapse." CEDES, Buenos Aires, 46.

- (2012) "Exchange rate regimes in the major Latin American countries since the 1950s: lessons from history.” Revista De Historia Económica 30 (1): 157.

GALIANI, S., D. HEYMANN, and M. TOMMASI. (2003) "Expectativas frustradas: el ciclo de la convertibilidad.” Desarrollo Económico 43 (169): 3. 
GANAPOLSKY, E., and S. SCHMUKLER. (1998) "Crisis management in Argentina during the 1994-95 Mexican crisis: how did markets react?” World Bank Policy Research Working Paper, No. 1951. Http://Papers.Ssrn.Com/Sol3/Papers.Cfm?Abstract_Id=161348.

GERCHUNOFF, P. (2005) “El barrendero que limpia el camino.” Argumentos, No. 5 (Enero). Http:// Argumentos.Fsoc.Uba.Ar/N05/Articulos/Implicancias_El_Barrendero.Pdf.

GERCHUNOFF, P., and H. AGUIRRE. (2004) "La política económica de Kirchner en la Argentina: Varios estilos, una sola agenda”, Boletín Del Real Instituto Elcano De Estudios Internacionales Y Estratégicos 48.

GERCHUNOFF, P., E. GRECO, and D. BONDOREVSKY. (2003) Comienzos Diversos, Distintas Trayectorias Y Final Abierto: Más De Una Década De Privatizaciones En Argentina, 1990-2002. Vol. 34. Instituto Latinoamericana Y Del Caribe De Planificaci Nomica.

GERCHUNOFF, P., and J.C. TORRE. (1996) "La Política de liberalización económica en la administración de Menem." Desarrollo Económico 36 (143): 733.

HAUSMANN, R., and A. VELASCO. (2002) "Hard money's soft underbelly: understanding the Argentine crisis." In Brookings Trade Forum, 2002:59-104. Http://Muse.Jhu.Edu/Journals/Btf/Summary/V2002/2002.1hausmann.Html.

HEYMANN, Daniel. (2000) Políticas de Reforma y Comportamiento Macroeconómico: La Argentina en los Noventa. Naciones Unidas, Comisión Económica Para América Latina Y El Caribe. Http://200.9.3.98/Publicaciones/Xml/2/4912/Lcl1357e.Pdf.

KIGUEL, M. A. (2007) Entrevista a Miguel Kiguel, Secretario De Finanzas 1996-99Video Digital. 67. Archivo De Historia Oral De La Argentina Contemporánea. IIGG, UBA. Http://Www.Archivooral. Org/Busqueda_Entrevista.Php?Id=67.

KYDLAND, F. E., and E. C. PRESCOTT. (1977) "Rules rather than discretion: the inconsistency of optimal plans." The Journal of Political Economy 85 (3): 473.

LA NACIÓN. (1999) "Menem plantea pagar sueldos en dólares.” La Nación, May 29. Http://Www. Lanacion.Com.Ar/140118-Menem-Plantea-Pagar-Sueldos-En-Dolares.

LEVY YEYATI, E. (2002) "Dolarización financiera y crisis bancaria." Mimeo, UTDT, July, 15.

LEVY YEYATI, E., and F. STURZENEGGER. (2007) "Fear of floating in reverse: exchange rate policy in the 2000s." LAMES-LACEA Annual Meetings.

LIENDO, H. (2006) Interview by M. Novaro and N. Cherny.

LLACH, J. (2006) Interview by N. Cherny, M. Novaro, And V. Palermo.

MACHINEA, J. L. (1999) La dolarización es mala, no soluciona ningún problema. Diario Clarin. Http://Www.Clarin.Com/Diario/1999/01/30/O-01104d.Htm.

MOBIUS, M. (1999) “Los mercados se están equivocando". Interview by A. Borenstein. Clarín. Http:// Edant.Clarin.Com/Suplementos/Economico/1999/01/10/O-00801e.Htm.

PALERMO, V. (1995) "Síganme! Las feformas estructurales como procesos políticos: el caso argentino, 1989-1993”. Doctoral Thesis. Madrid: Universidad Complutense De Madrid.

- (2004) "Estrategias risgosas. racionalidad política y gestion económica de gobiernos representativos em Argentina y Brasil” In Política Brasileña Contemporánea. De Collor A Lula En Años De Transformación, Edited By V. Palermo. Buenos Aires: Instituto Torcuato Di Tella - Siglo XXI De Argentina Editores.

PALERMO, V., and J.C. TORRE. (1994) "A la sombra de la hiperinflación. La política de reformas estructurales en Argentina.” Mimeo, UTDT, September, 25.

PERSSON, T., and G. TABELLINI. (2002) Political Economics. MIT Press.

PORTA, F. (1995) Cuatro Años con Tipo de Cambio Fijo: Ajuste Estructural O Ajuste Recesivo? Centro De Investigaciones Para La Transformación. Http://Www.Fund-Cenit.Org.Ar/Descargas/Dt21.Pdf.

RAPETTI, M. (2005) “La macroeconomía Argentina durante la post-convertibilidad." The Argentina Observatory -Economics Working Group, No. 5 (October): 37.

REMES LENICOV, J., J. TODESCA, and E. RATTI, (2003) “2002: Cambios profundos para superar la crisis provocada por el colapso de la convertibilidad y sentar las bases para el funcionamiento de una economia normal, integrada al mundo". Buenos Aires.

ROSALES, J. (1999) “El gobierno no deja la dolarización.” La Nación, February 26. Http://Www.Lanacion.Com.Ar/129219-El-Gobierno-No-Deja-La-Dolarizacion.

ROSALES, J., and M. OBARRIO (1999) "Menem apura una dolarización de hecho." La Nación, May 28. Http://Www.Lanacion.Com.Ar/140045-Menem-Apura-Una-Dolarizacion-De-Hecho. 